\title{
Characteristics of isolated lactic acid bacteria and their effects on the silage quality
}

\author{
Siran Wang ${ }^{1}$, Xianjun Yuan ${ }^{1}$, Zhihao Dong ${ }^{1}$, Junfeng Li ${ }^{1}$, Gang Guo ${ }^{2}$, Yunfeng Bai ${ }^{3}$, \\ Junyu Zhang', and Tao Shao ${ }^{1, *}$
}

${ }^{*}$ Corresponding Author: Tao Shao

E-mail: taoshaolan@163.com

'Institute of Ensiling and Processing of Grass, Nanjing Agricultural University, Nanjing 210095, China

${ }^{2}$ College of Animal Science and Veterinary Medicine, Shanxi Agricultural University, Taigu 030801, China

3 Jiangsu Academy of Agricultural Science, Nanjing 210014, China

Submitted Aug 5, 2016; Revised Sept 11, 2016; Accepted Oct 7, 2016
Objective: Four lactic acid bacteria (LAB) strains isolated from common vetch, tall fescue and perennial ryegrass on the Tibetan Plateau were characterized, and their effects on the fermentation quality of Italian ryegrass (Lolium multiflorum Lam.) silage were studied.

Methods: The four isolated strains and one commercial inoculant (G, Lactobacillus plantarum MTD-1) were evaluated using the acid production ability test, morphological observation, Gram staining, physiological, biochemical and acid tolerance tests. The five LAB strains were added to Italian ryegrass for ensiling at three different temperatures $\left(10^{\circ} \mathrm{C}, 15^{\circ} \mathrm{C}\right.$, and $\left.25^{\circ} \mathrm{C}\right)$.

Results: All isolated strains (LCG3, LTG7, I5, and LI3) could grow at $5^{\circ} \mathrm{C}$ to $20^{\circ} \mathrm{C}$, pH 3.0 to 8.0 and $\mathrm{NaCl}(3.0 \%, 6.5 \%)$. Strains LCG3, LTG7, I5, and LI3 were identified as Lactobacillus plantarum, Pediococcus acidilactici, Lactobacillus paraplantarum, and Lactobacillus casei by sequencing $16 \mathrm{~S} \mathrm{rDNA}$, respectively. All LAB inoculants significantly $(\mathrm{p}<0.05)$ increased lactic acid (LA) contents and ratios of lactic acid to acetic acid, and reduced $\mathrm{pH}$ and ammonia nitrogen/ total nitrogen $(\mathrm{AN} / \mathrm{TN})$ compared with uninoculated silages at various temperatures $\left(10^{\circ} \mathrm{C}\right.$, $15^{\circ} \mathrm{C}$, and $\left.25^{\circ} \mathrm{C}\right)$. Compared to the commercial inoculant $\mathrm{G}$, I5, and LI3 showed similar effects on improving the silage quality of Italian ryegrass at $10^{\circ} \mathrm{C}$ and $15^{\circ} \mathrm{C}$, indicated by similar $\mathrm{pH}$, LA content and AN/TN.

Conclusion: All inoculants could improve the silage fermentation quality at various temperatures $\left(10^{\circ} \mathrm{C}, 15^{\circ} \mathrm{C}\right.$, and $\left.25^{\circ} \mathrm{C}\right)$. At the temperature of $10^{\circ} \mathrm{C}$ and $15^{\circ} \mathrm{C}$, strain I5 and LI3 had similar effects with the commercial inoculant $\mathrm{G}$ on improving the silage quality of Italian ryegrass.

Keywords: Isolation; Lactic Acid Bacteria; Silage; Low Temperature

\section{INTRODUCTION}

Tibetan Plateau, located in southwest China with an average elevation of 4,000 $\mathrm{m}$ above sea level, is regarded as the Earth's third pole and the highest unique territorial unit in the world. In this distinct ecological region, the unique geographical and climatic conditions of Tibetan Plateau have contributed to the formation of specific microorganisms found in forage crops and grasses [1]. Thus, it is significant to explore the specific microorganism resource on the Tibetan Plateau. In addition, conditions are often unsuitable for crops on the Tibetan Plateau due to unstable climate and natural environment, particularly severe frosts from November to early April [2]. Therefore, forage preservation is a desirable strategy for sustainable development of livestock production in Tibet.

Ensiling is a major method of forage conservation, and it is based on natural fermentation in which epiphytic lactic acid bacteria (LAB) convert water-soluble carbohydrates (WSC) into lactic acid (LA) under anaerobic conditions. As a result, the $\mathrm{pH}$ decreases and the forage is preserved [3]. The success of the ensiling process depends, to a great extent, on the epiphytic LAB present in the crop, and it is common to improve the silage quality by application of inoculants. How- 
ever, the efficiency of LAB inoculants might be strongly influenced by the temperature within the silage [3]. In Tibet, especially during the frosts, the low temperature is considered as a main factor resulting in poor silage, and most of commercial LAB inoculants are often of little or even no benefit to silage under low temperature conditions [4]. Besides, in most of the literature describing ensiling experiments, there is seldom reference to low temperature ensiling. Therefore, it is necessary to isolate and study potential $\mathrm{LAB}$ capable of playing a positive role under low temperature conditions, which is a necessary approach for improving the silage quality in the frigid climate zones.

The objective of this study was to examine the characteristics of isolated LAB and their effects on fermentation quality of Italian ryegrass (Lolium multiflorum Lam.) silage at different storage temperatures $\left(10^{\circ} \mathrm{C}, 15^{\circ} \mathrm{C}\right.$, and $\left.25^{\circ} \mathrm{C}\right)$, and to make full use of local LAB resources on the Tibetan Plateau.

\section{MATERIALS AND METHODS}

\section{Lactic acid bacteria strains}

A total of $20 \mathrm{LAB}$ strains were isolated from common vetch, tall fescue and perennial ryegrass silages (laboratory silos; $450 \mathrm{~mL}$ capacity/silo). These forage crops were harvested at a maturity of pod bearing period, heading period and heading period, respectively and ensiled on September 28th, 2013 at Shigatse Grassland Station (Tibet, China: N $29^{\circ} 16^{\prime}$, E $88^{\circ} 51^{\prime}$, elevation 3,836 meters, annual mean temperature $6.5^{\circ} \mathrm{C}$ and average annual precipitation $400 \mathrm{~mm}$ ) and fermented for 45 days at ambient temperatures. All the forage crops were well preserved despite the low temperature $\left(6.5^{\circ} \mathrm{C}\right.$ ). According to our previous experiment (not published), some epiphytic LAB contribute to the good fermentation quality of common vetch, tall fescue and perennial ryegrass silages at low environmental temperatures in Tibet, and these were a good donor source for low temperature-resistant LAB isolation. The $20 \mathrm{LAB}$ strains isolated were tested for low temperature resistance using the methodology described by Cai et al [5] and only four strains (LCG3, LTG7, I5, and LI3) were selected. Gram stain, colony morphology, catalase activity and gas production from glucose were determined according to Kozaki et al [6]. Growth at different $\mathrm{pH}$ was observed in de Man, Rogosa, Sharpe (MRS) broth (adjusting $\mathrm{pH}$ with $\mathrm{HCl}$ or $\mathrm{NaOH}$ ), after incubation at $35^{\circ} \mathrm{C}$ for 2 days. Growth at different temperatures was observed in MRS broth after incubation at $5^{\circ} \mathrm{C}, 10^{\circ} \mathrm{C}, 15^{\circ} \mathrm{C}$, and $20^{\circ} \mathrm{C}$ for 5 days. The salt tolerance of $\mathrm{LAB}$ strains was tested using MRS broth containing $\mathrm{NaCl}$ at 3\% and 6.5\% after incubation at $35^{\circ} \mathrm{C}$ for 2 days. Carbohydrate fermentation of 49 different compounds was examined by API $50 \mathrm{CHL}$ assay (BioMérieux, Marcy l' Etoile, Lyons, France) according to the manufacturer's instruction. Lactobacillus plantarum MTD-1, a commercial LAB inoculant (G; Ecosyl. Products. Inc. Madison, WI, USA) that is a high-performance silage inoculant and works well in both high- and low-dry matter (DM) silage over a wide $\mathrm{pH}$ (7.5 to $3.5)$ and temperature $\left(7.8^{\circ} \mathrm{C}\right.$ to $\left.45^{\circ} \mathrm{C}\right)$ range was used as positive control for silage making.

\section{Extraction of lactic acid bacteria genomic DNA}

Each strain was cultivated in $5 \mathrm{~mL}$ of MRS medium at $37^{\circ} \mathrm{C}$ overnight and centrifuged at $10,000 \times \mathrm{g}$ for $5 \mathrm{~min}$. The cells were washed twice with buffer $(10 \mathrm{mmol} / \mathrm{L}$ Tris- $\mathrm{HCl}, 0.1 \mathrm{mmol} / \mathrm{L}$ ethylenediaminetetraacetic acid [EDTA], $\mathrm{pH}$ 8.0) in a clean 1.5 $\mathrm{mL}$ microcentrifuge tube and recentrifuged. Genomic DNA was extracted by a TIANamp Bacteria DNA Kit (Tiangen Biotech Co., Ltd, Beijing, China) following the manufacturer's instructions [7]. The genomic DNA concentration of each strain was determined at $260 \mathrm{~nm}$ by spectrophotometer. The extracted genomic DNA of each strain was stored at $-20^{\circ} \mathrm{C}$ until use.

\section{Species identification by $16 \mathrm{~S}$ rRNA sequencing}

The 16S rRNA coding region was amplified by polymerase chain reaction (PCR). One microlitre of diluted DNA was used as a template for the PCR reactions. The PCR primers were $27 \mathrm{f}(5$ 'AGAGTTTGATCCTGGCTCAG-3') and 1492r (5'-TACGGCT ACCTTGTTACGACT-3') [5]. The PCR reaction was performed in $0.2 \mathrm{~mL}$ microcentrifuge tubes with $25 \mu \mathrm{L}$ of reaction mixture according to the protocol described by Escalante et al [8] with slight modification: DNA template (approximately $80 \mathrm{ng}$ ), 10× PCR buffer (0.1 mol/L Tris-HCl, pH 8.0, $0.5 \mathrm{~mol} / \mathrm{L} \mathrm{KCl}), 1.5$ $\mathrm{mmol} / \mathrm{L} \mathrm{MgCl}_{2} \mathrm{pH}$ 8.0, $100 \mu \mathrm{mol} / \mathrm{L}$ of each dNTP, AmpliTaq DNA recombinant polymerase $(1 \mathrm{U})$ (all PCR reagents were obtained from Tiangen Biotech Co., Ltd., China). Primer $27 \mathrm{f}$ $(0.4 \mu \mathrm{mol} / \mathrm{L})$ and primer $1492 \mathrm{r}(0.4 \mu \mathrm{mol} / \mathrm{L})$ were made up to $25 \mu \mathrm{L}$ with sterile distilled water. The PCR protocol was as follows: $95^{\circ} \mathrm{C}$ for $5 \mathrm{~min}$, followed by 30 cycles of denaturation at $94^{\circ} \mathrm{C}$ for $30 \mathrm{~s}$, primer annealing at $55^{\circ} \mathrm{C}$ for $1 \mathrm{~min}$, elongation at $72^{\circ} \mathrm{C}$ for $1.5 \mathrm{~min}$ and thermal retardation at $72^{\circ} \mathrm{C}$ for $10 \mathrm{~min}$. A $1 \mu \mathrm{L}$ sample of reaction mixture was analyzed by $1.5 \%$ agarose gel electrophoresis in Tris-borate EDTA (TBE) $1 \times$ buffer. The gel was stained with GoldView and the bands were visualized under UV illumination. The PCR products were purified using the DNA purification systems according to the manufacturer's instructions (Promega, Madison, WI, USA) for $16 \mathrm{~S}$ rRNA sequencing analysis. The 16S rDNA sequences were aligned with 16S rRNA sequences from GenBank to identify organisms using BLAST analysis [9]. Then, the sequence information from representative organisms was introduced into the CLUSTALW program (Hitachi Software Engineering Co., Tokyo, Japan) for assembly and alignment. The $16 \mathrm{~S}$ rRNA gene sequences of isolates were compared with sequences from LAB-type strains held in GenBank. Nucleotide substitution rates were calculated and phylogenetic trees were constructed by the neighbor-joining method based on 1,000 random resamplings.

\section{Silage making}


Italian ryegrass was harvested at the boot stage of maturity in the experiment field of the Shigatse District Grassland Station on 7 July 2014, and was chopped to a theoretical cut length of $2 \mathrm{~cm}$ using a paper-cutter. LAB inoculation (LCG3, LTG7, I5, $\mathrm{LI} 3$, and $\mathrm{G})$ and the control at different storage temperatures $\left(10^{\circ} \mathrm{C}, 15^{\circ} \mathrm{C}\right.$, and $\left.25^{\circ} \mathrm{C}\right)$ were designed as follows: all LAB strains were inoculated at $1 \times 10^{5}$ colony-forming units ( $\mathrm{cfu}$ )/g of fresh material, and the same volume of distilled water was used for the control. About $650 \mathrm{~g}$ of fresh material was tightly packed into a plastic polyethylene bottle ( $1 \mathrm{~L}$ capacity; about $650 \mathrm{~kg} / \mathrm{m}^{3}$ fresh weight) and sealed with a screw top and plastic tapes. Five replicates were made for each treatment, and ninety bottles in total ( 6 inoculant treatments $\times 3$ temperatures $\times 5$ replicates $=90$ ) were prepared. Silos for each treatment were stored in the incubators according to the design temperatures, and for simulating the production practice, we chose 35 days to assess the practical feasibility of silage making in Tibet.

\section{Chemical and microbial analyses}

When the bottle silos were opened, the silage was mixed thoroughly, and a $35 \mathrm{~g}$ sample was taken from each bottle, mixed with $70 \mathrm{~mL}$ distilled water and stored in a refrigerator at $4^{\circ} \mathrm{C}$ for $24 \mathrm{~h}$. Then the extracts were filtered through two layers of cheesecloth and a filter paper. The filtrate was used for chemical analyses [10] and its $\mathrm{pH}$ was measured immediately with a glass electrode $\mathrm{pH}$ meter (HANNA pH 211, Hanna Instruments Italia Srl, Villafranca Padovana, Italy). Buffering capacity (BC) was determined by Playne and McDonald [11]. The DM was determined by oven drying at $65^{\circ} \mathrm{C}$ for $48 \mathrm{~h}$ to a constant mass, and then ground to pass through a $1 \mathrm{~mm}$ screen for later analysis. The WSC content was analyzed by colorimetric after-reaction with anthrone reagent [12]. The ammonia nitrogen (AN) content was determined by the phenol-hypochlorite procedure [13]. Total nitrogen (TN) content was determined according to Kjeldahl procedure [14]. Crude protein (CP) content was calculated by multiplying TN by 6.25 (since plant protein contains $16 \% \mathrm{~N}$ ). Organic acid and ethanol contents of the silage were analyzed using the Agilent HPLC 1260 (Agilent Technologies, Inc., Berlin, Germany; column: Carbomix H-NP5, Sepax Technologies, Inc., Santa Clara, CA, USA; detector: refractive index detector, Agilent Technologies, Inc., Germany; eluent: $2.5 \mathrm{mmol} / \mathrm{L} \mathrm{H}_{2} \mathrm{SO}_{4}, 0.5$ $\mathrm{mL} / \mathrm{min}$; temperature: $55^{\circ} \mathrm{C}$ ).

About $10 \mathrm{~g}$ of silage was blended with $90 \mathrm{~mL}$ of sterilized saline solution $(0.85 \% \mathrm{NaCl})$, and the extract was serially diluted to quantify the microbial group in sterile saline solution. LAB were counted on de Man, Rogosa and Sharpe agar medium (Difco Laboratories, Detroit, MI, USA) after incubation in an anaerobic incubator $\left(\mathrm{N}_{2}: \mathrm{H}_{2}: \mathrm{CO}_{2}=85: 5: 10\right.$, YQX-II; CIMO Medical Instrument Manufacturing Co., Ltd, Shanghai, China) at $37^{\circ} \mathrm{C}$ for 2 to 3 days. Aerobic bacteria were counted on nutrient agar (NissuiSeiyaku Ltd, Tokyo, Japan) and yeasts were counted on potato dextrose agar (Nissui-Seiyaku Ltd, Japan) acidified with sterilized tartaric acid solution to $\mathrm{pH}$ 3.5. The agar plates were incubated at $37^{\circ} \mathrm{C}$ for 3 days. All microbial data were transformed to $\log _{10}$ and are presented on a fresh weight basis.

\section{Data analysis}

The 16S rRNA sequences of the LAB isolates were analyzed using MEGA 6.0 for Windows (The Biodesign Institute, Tempe, AZ, USA). The data of silage fermentation quality, chemical composition and microbial counts were analyzed using the general linear model procedure according to the model for a factorial treatment design as follows:

$$
\mathrm{Y}_{i j}=\mu+\mathrm{I}_{i}+\mathrm{T}_{j}+(\mathrm{I}+\mathrm{T})_{i j}+\mathrm{e}_{i j}
$$

Where $Y_{i j}$ is the dependent variable; $\mu$ is overall mean; $I_{i}$ is the effect of LAB inoculation; $\mathrm{T}_{j}$ is the effect of temperature; $(\mathrm{I}+\mathrm{T})_{i j}$ is the effect of interaction between $\mathrm{LAB}$ inoculation and temperature; and $e_{i j}$ is the residual error term. The effects were considered significant at $\mathrm{p}<0.05$, Tukey's tests were used for means separation. All statistical procedures were performed with Statistical package for the Social Sciences (SPSS 16.0 for windows; SPSS Inc., Chicago, IL, USA).

\section{RESULTS}

\section{Lactic acid bacteria strain characteristics}

The morphological and physiological characteristics of the five LAB strains used in this experiment are presented in Table 1. All LAB strains were Gram-positive, homofermentative and catalase-negative. The strains LCG3, I5, LI3, and G were rodshaped, while strain LTG7 was cocci-shaped bacteria. All isolated strains (LCG3, LTG7, I5, and LI3) could grow at $5^{\circ} \mathrm{C}$ to $20^{\circ} \mathrm{C}$, pH 3.0 to 8.0 and $\mathrm{NaCl}(3.0 \%, 6.5 \%)$. All strains could ferment galactose, cellobiose and mannitol, whereas none of them could utilize starch. Strains LTG7, I5, and G could ferment rhamnose while strains LCG3 and LI3 could not.

Molecular homological analysis was conducted and the phylogenetic tree was constructed based on the $16 \mathrm{~S}$ rDNA sequences for observing divergences. The phylogenetic tree of partial 16S rDNA sequences of LCG3, LTG7, I5, and LI3 is presented in Figure 1. Strain LCG3 was most closely related to Lactobacillus plantarum, supporting the $98 \%$ value from bootstrap analysis of the phylogenetic tree (Figure 1), and showing 100\% similarity in its $16 \mathrm{~S}$ rDNA gene sequences. With $100 \%$ similarity in their $16 \mathrm{~S}$ rDNA gene sequences, strain LTG7 was most closely related to the Pediococcus acidilactici and strain I5 was most closely related to Lactobacillus paraplantarum and strain LI3 was most closely related to Lactobacillus casei, all supporting the $99 \%$ values from the bootstrap analysis of the phylogenetic tree (Figure 1). The accession numbers of LCG3, LTG7, I5, and LI3 were KJ806299, KJ806304, KJ806310, and KJ806307, respectively. 
Table 1. The characteristics of lactic acid bacteria strains

\begin{tabular}{|c|c|c|c|c|c|}
\hline Item & LCG3 & LTG7 & 15 & LI3 & G \\
\hline Shape & Rod & Cocci & Rod & Rod & Rod \\
\hline Fermentation type & Homo & Homo & Homo & Homo & Home \\
\hline Gram stain & $+^{1)}$ & + & + & + & + \\
\hline Catalase activity & - & - & - & - & - \\
\hline Gas from glucose & - & - & - & - & - \\
\hline \multicolumn{6}{|l|}{ Growth at temperature $\left({ }^{\circ} \mathrm{C}\right)$} \\
\hline 5 & + & + & + & + & - \\
\hline 10 & + & + & + & + & + \\
\hline 15 & + & + & + & + & + \\
\hline 20 & + & + & + & + & + \\
\hline \multicolumn{6}{|l|}{ Growth at pH } \\
\hline 3.0 & + & + & + & + & - \\
\hline 3.5 & + & + & + & + & + \\
\hline 4.0 & + & + & + & + & + \\
\hline 4.5 & + & + & + & + & + \\
\hline 5.0 & + & + & + & + & + \\
\hline 7.5 & + & + & + & + & + \\
\hline 8.0 & + & + & + & + & + \\
\hline \multicolumn{6}{|l|}{ Growth in $\mathrm{NaCl}$} \\
\hline $3 \% \mathrm{NaCl}$ & + & + & + & + & + \\
\hline $6.5 \% \mathrm{NaCl}$ & + & + & + & + & + \\
\hline \multicolumn{6}{|l|}{ Carbohydrate fermentation } \\
\hline L-Arabinose & + & ++ & - & - & + \\
\hline Galactose & ++ & ++ & ++ & ++ & + \\
\hline D-Fructose & ++ & ++ & ++ & ++ & + \\
\hline Rhamnose & - & + & + & - & + \\
\hline Dulcitol & - & - & - & ++ & - \\
\hline Mannitol & ++ & ++ & ++ & ++ & + \\
\hline Sorbitol & ++ & ++ & - & ++ & + \\
\hline a-Methyl-D-mannoside & ++ & - & - & - & + \\
\hline a -Methyl-D-glucoside & - & - & - & ++ & + \\
\hline Cellobiose & ++ & ++ & ++ & ++ & + \\
\hline Maltose & ++ & ++ & ++ & ++ & - \\
\hline Lactose & ++ & ++ & ++ & - & + \\
\hline Melibiose & ++ & ++ & ++ & - & + \\
\hline Saccharose & ++ & ++ & ++ & ++ & + \\
\hline$\beta$-Gentiobiose & + & + & + & - & + \\
\hline D-Turanose & ++ & ++ & - & ++ & - \\
\hline D-Tagatose & - & - & - & ++ & - \\
\hline D-Arabitol & + & - & + & - & - \\
\hline Gluconate & W & + & + & + & - \\
\hline
\end{tabular}

Homo, homofermentative; Hetero, heterofermentative.

1) ++ , good growth; +, normal growth; w, weak growth; -, no growth.

The rest of carbohydrates were not fermented by five strains and not listed.

\section{Forage characteristics}

The chemical and microbiological characteristics of Italian ryegrass prior to ensiling are given in Table 2. The DM content was $240.6 \mathrm{~g} / \mathrm{kg}$ fresh matter (FM) and WSC content was $103.5 \mathrm{~g} / \mathrm{kg}$ DM. The BC and CP content were $82.3 \mathrm{mEq} / \mathrm{kg} \mathrm{DM}$ and 64.9 $\mathrm{g} / \mathrm{kg} \mathrm{DM}$, respectively. The numbers of LAB, aerobic bacteria and yeasts on the material were 4.12, 6.12, and $4.25 \mathrm{log} \mathrm{cfu} / \mathrm{g} \mathrm{FM}$, respectively.

Effects of lactic acid bacteria inoculation
As shown in Table 3, storage temperatures, LAB inoculations and their interaction significantly $(\mathrm{p}<0.01)$ affected the fermentation characteristics of Italian ryegrass silage. Compared to the corresponding controls at three different temperatures, all these LAB strains significantly $(\mathrm{p}<0.05)$ reduced $\mathrm{pH}$ and ammonia nitrogen/ total nitrogen $(\mathrm{AN} / \mathrm{TN})$, and significantly $(\mathrm{p}<0.05)$ increased lactic acid and residual WSC contents, and ratios of lactic acid to acetic acid (LA/AA) of the silage. In addition, no or only trace amounts of propionic and butyric acid were found in most silages (data not shown). Compared to the corresponding positive controls $\mathrm{G}$ at various temperatures, marked increases $(\mathrm{p}<0.05)$ in lactic acid content occurred, resulting in lower $(\mathrm{p}<0.05) \mathrm{pH}$ and AN/TN in I5-inoculated silage. At $25^{\circ} \mathrm{C}$, compared to G, LI3 showed the similar $\mathrm{pH}(\mathrm{p}<0.05)$, while in LTG7-inoculated silage, the $\mathrm{pH}$ declined and lactic acid content increased $(\mathrm{p}<0.05)$. At $15^{\circ} \mathrm{C}, \mathrm{LI} 3$ and LCG3 showed lower $\mathrm{pH}$ and AN/TN, and higher lactic acid contents and ratios of LA/AA than $\mathrm{G}(\mathrm{p}<0.05)$. At $10^{\circ} \mathrm{C}, \mathrm{I} 5, \mathrm{LI} 3$, and LTG7 had a higher ratio of LA/AA than G $(p<0.05)$. In addition, $G$ showed the lowest ratio of LA/AA among the five inoculants at $15^{\circ} \mathrm{C}$ and $25^{\circ} \mathrm{C}(\mathrm{p}<0.05)$, respectively.

As seen in Table 4, storage temperatures, LAB inoculations and their interaction significantly $(\mathrm{p}<0.01)$ affected the microorganism populations of Italian ryegrass silage. Compared to the corresponding controls at three different temperatures, all the inoculants significantly $(\mathrm{p}<0.05)$ decreased aerobic bacteria counts, and significantly ( $\mathrm{p}<0.05)$ increased LAB counts of the silage. Compared to the corresponding $\mathrm{G}$ at various temperatures, I5 had lower aerobic bacteria and yeast counts, and higher LAB count $(\mathrm{p}<0.05)$. At $25^{\circ} \mathrm{C}, \mathrm{LI} 3$ and LTG7 had higher LAB counts than $\mathrm{G}(\mathrm{p}<0.05)$. At $15^{\circ} \mathrm{C}, \mathrm{LI} 3, \mathrm{LCG} 3$, and LTG7 showed lower aerobic bacteria counts and higher LAB counts than $G(p<0.05)$. At $10^{\circ} \mathrm{C}$, LI3 and LCG3 decreased aerobic bacteria and yeast counts as compared with $\mathrm{G}$. Besides, the highest yeast count was observed in $\mathrm{G}$ inoculated silage among the all treatments at $10^{\circ} \mathrm{C}$ $(\mathrm{p}<0.05)$.

Comparison of the uninoculated silages at three different temperatures indicated that the silage at $10^{\circ} \mathrm{C}$ showed higher $\mathrm{pH}$, AN/TN and aerobic bacteria count, and lower lactic acid, acetic acid contents, ratio of $\mathrm{LA} / \mathrm{AA}$ and $\mathrm{LAB}$ count than that at $15^{\circ} \mathrm{C}$ and $25^{\circ} \mathrm{C}(\mathrm{p}<0.05)$.

\section{DISCUSSION}

Strains I5 and LCG3, which belong to L. paraplantarum and $L$. plantarum (Table 1) respectively, showed high tolerance to low $\mathrm{pH}$ and temperature, which are consistent with the findings of Pang et al [15]. LTG7 could grow at $\mathrm{pH} 3.0$ and $10^{\circ} \mathrm{C}$, and it was different from Pediococcus acidilactici isolated from forage crops by Cai et al [5]. All four isolated strains (LCG3, LTG7, I5, and LI3) could grow at $5^{\circ} \mathrm{C}$ and $\mathrm{pH} 3.0$, indicating the psychrotolerant nature and the tolerance to acidity of these strains, and satisfying the demands for growth in low $\mathrm{pH}$ and temperature environ- 


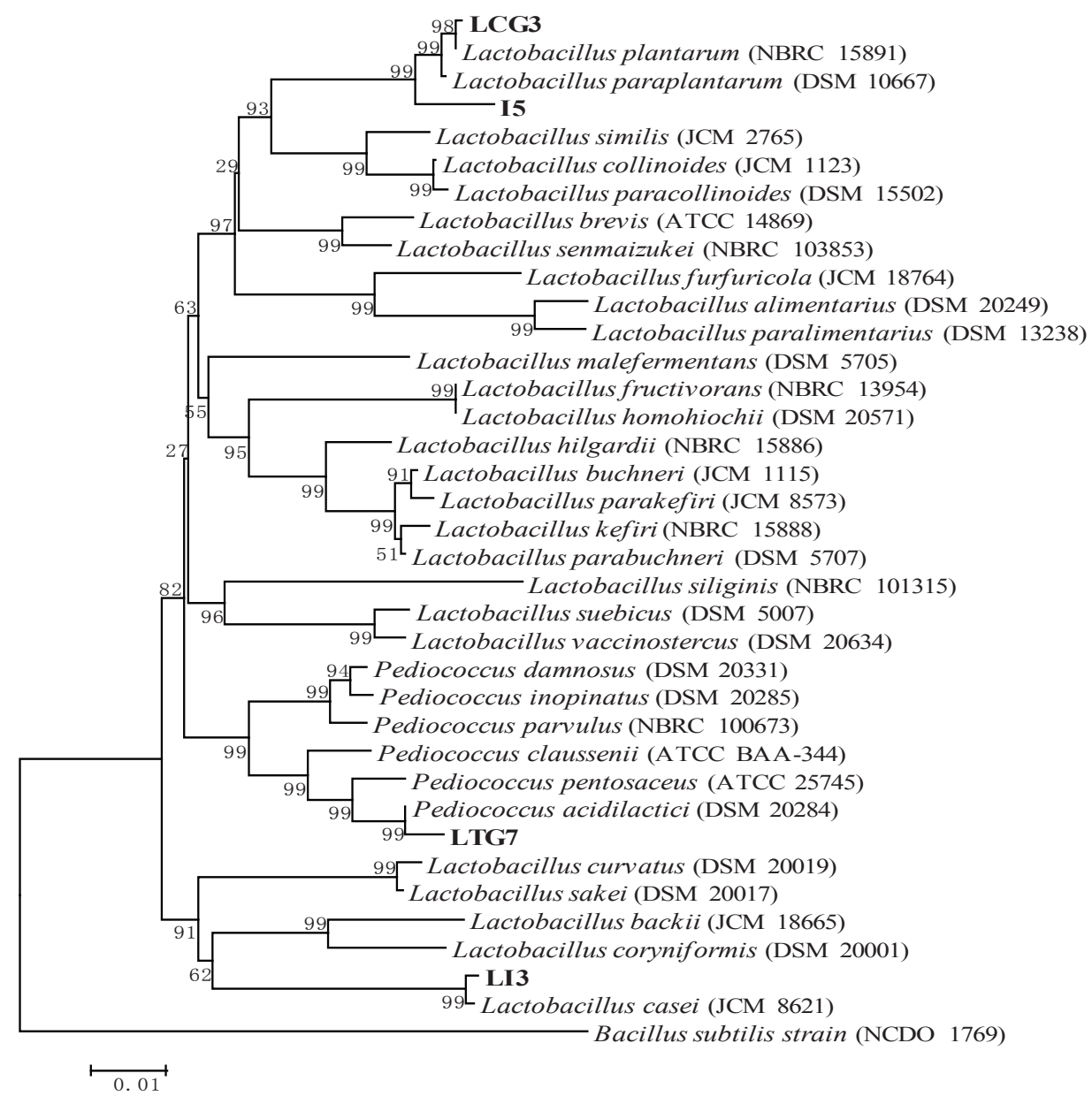

Figure 1. Phylogenetic tree of partial $165 \mathrm{rDNA}$ sequences of isolated strains and sequences of identified bacteria in the nucleotide database of GenBank. The bar indicates $1 \%$ sequence divergence.

ments. The phenotyping procedures used to assign isolates to known species are difficult, making it hard to differentiate between species. However, as reported in some studies $[9,16]$, the $16 \mathrm{~S}$ rDNA sequence analysis method is very good at identifying the organisms by genus and species. Molecular homological analysis was conducted, and phylogenetic trees were constructed based on the $16 \mathrm{~S}$ rDNA sequences for observing divergences. Consequently, strains LCG3, LTG7, I5, and LI3 could be identified

Table 2. Chemical (g/kg DM) and microbial (log cfu/g FM) compositions of Italian ryegrass prior to ensiling

\begin{tabular}{lc}
\hline Items & Italian ryegrass \\
\hline DM (g/kg FM) & 240.6 \\
CP & 64.9 \\
WSC & 103.5 \\
BC (mEg/kg DM) & 82.3 \\
Lactic acid bacteria & 4.12 \\
Aerobic bacteria & 6.12 \\
Yeasts & 4.25 \\
\hline
\end{tabular}

DM, dry matter; log, denary logarithm of the numbers; cfu, colony-forming units; FM, fresh matter; CP, crude protein; WSC, water soluble carbohydrates; BC, buffering capacity; $\mathrm{mEq}$, milligram equivalent. as Lactobacillus plantarum, Pediococcus acidilactici, Lactobacillus paraplantarum, and Lactobacillus casei, respectively.

In natural fermentation, the epiphytic LAB numbers of forage have become a significant factor in predicting the adequacy of silage fermentation and determining whether or not to apply bacterial inoculants to silage materials [17,18]. A well-preserved silage requires that lactobacilli reach a level of at least $10^{5} \mathrm{cfu} / \mathrm{g}$ FM at ensiling [19]. However, the number of epiphytic LAB on fresh crops is often very low, and this phenomenon was also evident in the present study $\left(<10^{5} \mathrm{cfu} / \mathrm{g}\right.$ FM; Table 2$)$. Additionally, ensiling is a fermentation process involving microbiological and enzymatic activity that is influenced by temperature [3]. In our study, the low lactic acid content, and high $\mathrm{pH}$ and AN/TN were observed in the corresponding controls at three different temperatures (Table 3, Figure 2). The inferior fermentation quality of control was more evident at $10^{\circ} \mathrm{C}$ than that at $15^{\circ} \mathrm{C}$ and $25^{\circ} \mathrm{C}$, as indicated by lower LA content and ratio of LA/AA, and higher $\mathrm{pH}$ and AN/TN (Table 3). It is speculated that such lower temperatures might inhibit the epiphytic LAB activity on the herbage. Hence, for improving the silage quality of Italian ryegrass at low temperatures, it is necessary to enhance the numbers and activity 
Table 3. Effects of LAB strains on the quality of Italian ryegrass silage at three different temperatures after 35 days ( $/ \mathrm{kg}$ DM)

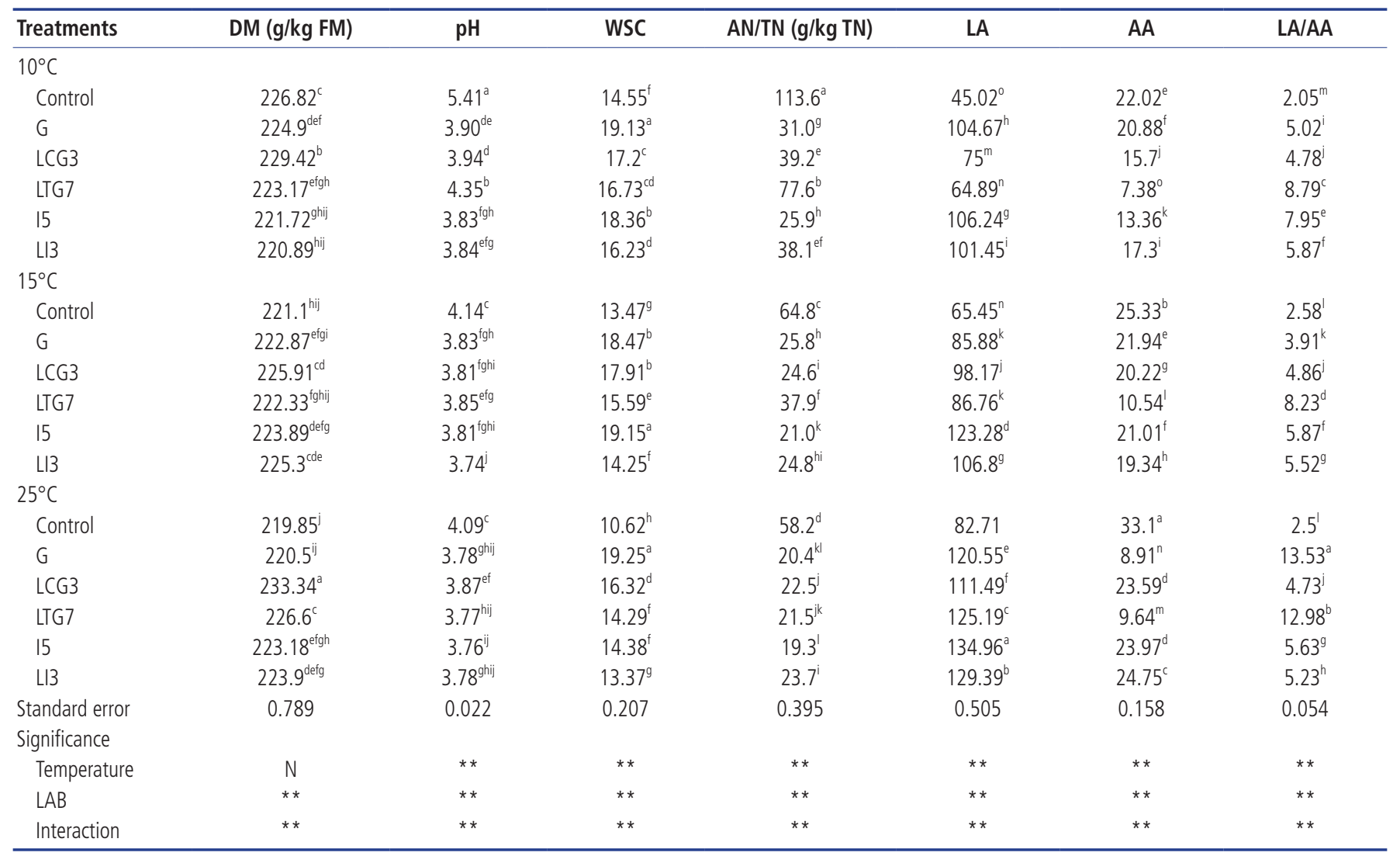

DM, dry matter; FM, fresh matter; WSC, water soluble carbohydrates; AN/TN, ammonia nitrogen/total nitrogen; LA, lactic acid; AA, acetic acid; LA/AA, lactic acid/acetic acid; G, commercial inoculant; LCG3, Lactobacillus plantarum; LTG7, Pediococcus pentosaceus; I5, Lactobacillus paraplantarum; LI3, Lactobacillus casei; N: not significant different. Values with different superscripts differ significantly $(p<0.05)$.

* Significant different in 0.05 values; ${ }^{* *}$ Significant different in 0.01 values.

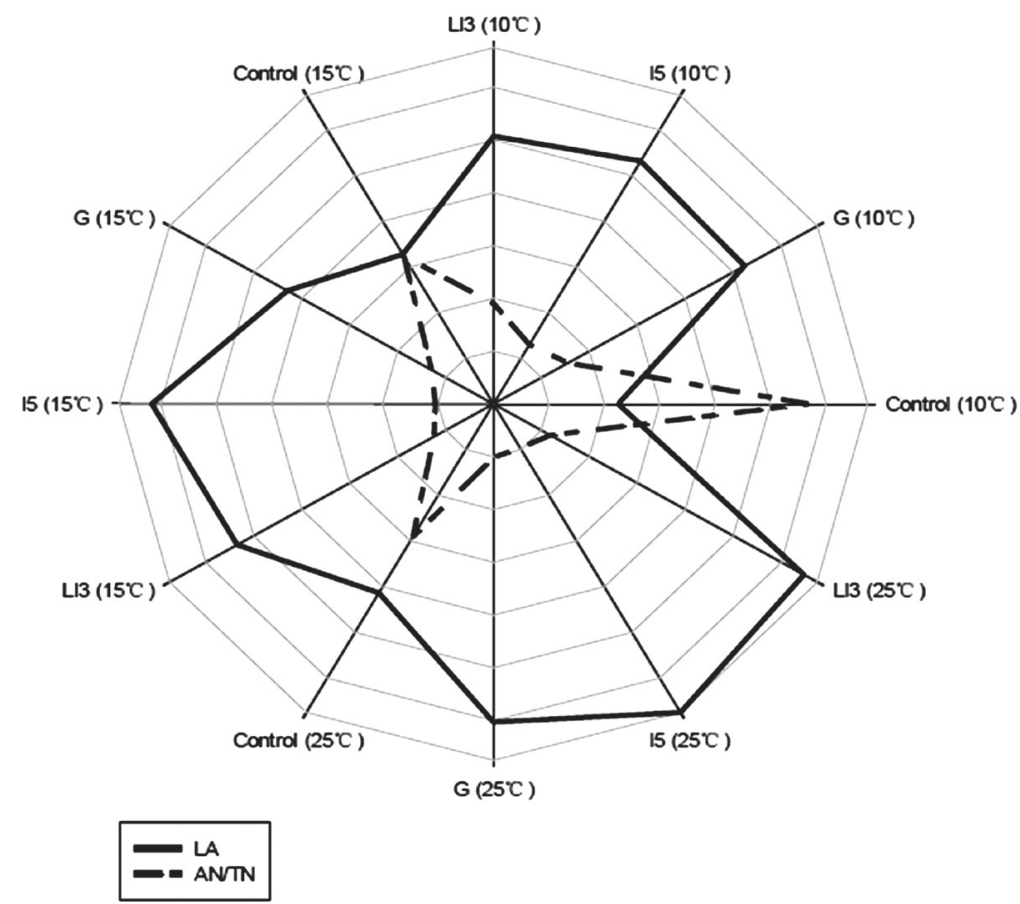

Figure 2. Effects of LAB strains on the LA (-) and AN/TN (- -) contents of Italian ryegrass silages at different temperatures after 35 days. 
Table 4. Effects of LAB strains on microorganism counts (log cfu g-1 FM) of Italian ryegrass silage at three different temperatures

\begin{tabular}{|c|c|c|c|}
\hline Treatments & Lactic acid bacteria & Aerobic bacteria & Yeasts \\
\hline \multicolumn{4}{|l|}{$10^{\circ} \mathrm{C}$} \\
\hline Control & $5.42^{i}$ & $7.03^{\mathrm{a}}$ & $4.03^{f}$ \\
\hline G & $8.54^{e}$ & $5.13^{j}$ & $3.91^{\dagger}$ \\
\hline LCG3 & $8.13^{f}$ & $4.63^{k}$ & $0^{j}$ \\
\hline LTG7 & $8.56^{e}$ & $5.8^{9}$ & $2.95^{h}$ \\
\hline 15 & $9.29^{d}$ & $4.14^{\mathrm{m}}$ & $2.03^{i}$ \\
\hline$L I 3$ & $8.7^{\mathrm{e}}$ & $4.46^{1}$ & $0^{j}$ \\
\hline \multicolumn{4}{|l|}{$15^{\circ} \mathrm{C}$} \\
\hline Control & $6.71^{\mathrm{h}}$ & $6.84^{\mathrm{b}}$ & $5.74^{\mathrm{a}}$ \\
\hline G & $8.2^{f}$ & $6.57^{\text {cd }}$ & $5.54^{b}$ \\
\hline LCG3 & $8.53^{e}$ & $6.06^{\dagger}$ & $0^{j}$ \\
\hline LTG7 & $8.6^{e}$ & $6.22^{\mathrm{e}}$ & $5.73^{\mathrm{a}}$ \\
\hline 15 & $9.82^{c}$ & $4.62^{k}$ & $0^{j}$ \\
\hline LI3 & $8.67^{e}$ & $5.83^{9}$ & $0^{j}$ \\
\hline \multicolumn{4}{|l|}{$25^{\circ} \mathrm{C}$} \\
\hline Control & $7.08^{9}$ & $6.62^{c}$ & $4.93^{c}$ \\
\hline G & $9.06^{d}$ & $5.7^{\mathrm{h}}$ & $4.68^{d}$ \\
\hline LCG3 & $8.58^{\mathrm{e}}$ & $6.16^{\mathrm{e}}$ & $3.78^{9}$ \\
\hline LTG7 & $9.96^{c}$ & $6.52^{d}$ & $4.45^{e}$ \\
\hline 15 & $11.27^{\mathrm{a}}$ & $5.59^{i}$ & $0^{j}$ \\
\hline LI3 & $10.31^{b}$ & $6.17^{e}$ & $0^{j}$ \\
\hline Standard error & 0.09 & 0.028 & 0.044 \\
\hline \multicolumn{4}{|l|}{ Significance } \\
\hline Temperatures & ** & ** & ** \\
\hline$\angle A B$ & ** & ** & ** \\
\hline Interaction & ** & ** & ** \\
\hline
\end{tabular}

FM, fresh matter; log, denary logarithm of the numbers; cfu, colony-forming units; $G$, commercial inoculant; LCG3, Lactobacillus plantarum; LTG7, Pediococcus pentosaceus; 15, Lactobacillus paraplantarum; LI3, Lactobacillus casei; N, not significant different. Values with different superscripts differ significantly $(p<0.05)$.

* Significant different in 0.05 values; ${ }^{* *}$ Significant different in 0.01 values.

of psychrotolerant LAB by applying LAB inoculants.

Inoculation with $\mathrm{LAB}$ at ensiling is commonly practiced throughout the world because it can promote lactic acid fermentation, inhibit the activity of undesired microbes and improve preservation $[20,21]$. In this study, as expected, the inoculated silages had lower $\mathrm{pH}$ and aerobic bacteria counts, and higher LA contents and $\mathrm{LAB}$ counts than the corresponding control silages at various temperatures. However, the effects of inoculation depend on many factors such as the properties of materials, LAB characteristics and environmental temperatures [22]. And for most bacteria, a temperature reduction causes a transient cell growth arrest, during which the general protein synthesis is severely inhibited, and the low temperature affects the viability and acidification activity of bacteria [23]. In the present study, among the same inoculated silages, with reduction in the storage temperatures, $\mathrm{pH}, \mathrm{AN} / \mathrm{TN}$ and aerobic bacteria count increased, and lactic acid content and LAB count decreased. However, even at low temperatures, the inoculated silage still maintained a lower $\mathrm{pH}$ and AN/TN, and higher lactic acid content than the control (Tables 3,4 ), and the silage quality of Italian ryegrass was improved by inoculants. This is in accordance with the original objective of screening LAB isolates for those that can survive in cold environment.

Among the five inoculants, only strain I5 and LI3 showed a high and consistent ability to produce acids even at $10^{\circ} \mathrm{C}$, as indicated by the medium $\mathrm{pH}$ after inoculation. Of the four isolates, I5 and LI3 showed similar effects with commercial inoculant G on improving silage quality, indicated by high lactic acid production ability, which remained higher than $100 \mathrm{~g} / \mathrm{kg} \mathrm{DM}$ at three different temperatures $\left(10^{\circ} \mathrm{C}, 15^{\circ} \mathrm{C}\right.$, and $\left.25^{\circ} \mathrm{C}\right)$. These results indicated that the isolated strains I5 and LI3 are more psychrotolerant than other isolated strains due to the long-term evolution and natural selection on the Tibetan Plateau, and they also might be associated with some cold stress genes [24]. The role for the heat shock proteins (Hsps) in preventing damage of LAB from low temperature has been suggested and $L$. plantarum strains overproducing Hsp 18.5, Hsp 18.55, and Hsp 19.3 can grow better at low temperature [23].

The inoculation of forage with homofermentative lactobacilli such as Lactobacillus casei or Lactobacillus plantarum had beneficial effects on promoting lactic acid fermentation and improving silage quality $[17,25]$. The homofermentative LABs are more efficient in lactic acid production than their heterofermentative counterparts and they can ferment a wide variety of substrates and quickly produce large amounts of lactic acid [20]. In this study, improvement in the fermentation quality of Italian ryegrass silage by inoculating $\mathrm{LAB}$ at three different temperatures of $10^{\circ} \mathrm{C}, 15^{\circ} \mathrm{C}$, and $25^{\circ} \mathrm{C}$ was indicated by higher ratios of LA/AA, which demonstrated a shift towards an enhanced homolactic fermentation of inoculated silages. The silage inoculated with $\mathrm{G}$ had a higher ratio of LA/AA than the silages with isolated LAB strains at $25^{\circ} \mathrm{C}$, whereas the silages inoculated with LTG7, I5, and LI3 at $10^{\circ} \mathrm{C}$ and $15^{\circ} \mathrm{C}$ had higher ratios of LA/AA than the silages inoculated with $\mathrm{G}$. There were no significant differences in the residual WSC contents between silages inoculated with LTG7 and $\mathrm{I} 5$ at $25^{\circ} \mathrm{C}$, whereas at $10^{\circ} \mathrm{C}$ and $15^{\circ} \mathrm{C}$ the I5-inoculated silage had higher residual WSC content than that inoculated with other isolated LAB strains. These results indicated that different temperatures had different effects on the WSC utilization and fermentation products of the silages inoculated with isolated $\mathrm{LAB}$ strains or G. Meanwhile, the higher ratio of LA/AA in Italian ryegrass silages inoculated with four isolates indirectly confirms the fact that all isolates were identified as homofermentative by morphological and physiological characteristics.

Quality silage should have $\mathrm{pH}$ of 4.20 or less, ammonia nitrogen content less than $100 \mathrm{~g} / \mathrm{kg} \mathrm{TN}$, butyric acid less than $10 \mathrm{~g} / \mathrm{kg}$ DM [20]. In this study, no or trace amount of butyric acid was found in most silages. This could be explained by the reduction in $\mathrm{pH}$ resulted from the addition of the isolates and low temperatures, which may have restricted the growth and proteolytic activity of microorganisms such as Clostridia [26,27]. In general, proteolytic activity decreases in the silage at lower $\mathrm{pH}$ condition. The low $\mathrm{pH}$ could also explain the decrease in AN/TN in in- 
oculated silages. This was also agreed with the results of Tabacco et al [28] and Guo et al [29].

In conclusion, Italian ryegrass is difficult to ensile on the Tibetan Plateau due to the low temperature. All inoculants could increase lactic acid contents, and reduce $\mathrm{pH}$ and $\mathrm{AN} / \mathrm{TN}$, and improve the silage fermentation quality at various temperatures $\left(10^{\circ} \mathrm{C}, 15^{\circ} \mathrm{C}\right.$, and $\left.25^{\circ} \mathrm{C}\right)$. At the temperature of $10^{\circ} \mathrm{C}$ and $15^{\circ} \mathrm{C}$, strain $\mathrm{I} 5$ and LI3 had similar effects with the commercial inoculant $\mathrm{G}$ on improving the silage quality of Italian ryegrass.

\section{CONFLICT OF INTEREST}

We certify that there is no conflict of interest with any financial organization regarding the material discussed in the manuscript.

\section{ACKNOWLEDGMENTS}

This work was supported by National Natural Science Foundation of China (31672488; 31502015), the Project of the Key Technologies R\&D Program of China during the 13th Five Year Plan period (2016YFC0502005), Jiangsu Independent Innovation (CX(15)1003-3) and Students Research Training (201510307038).

\section{REFERENCES}

1. Pang H, Tan Z, Qin G, et al. Phenotypic and phylogenetic analysis of lactic acid bacteria isolated from forage crops and grasses in the Tibetan Plateau. J Microbiol 2012;50:63-71.

2. Zhang J, Guo G, Chen L, et al. Effect of applying lactic acid bacteria and propionic acid on fermentation quality and aerobic stability of oats-common vetch mixed silage on the Tibetan plateau. Anim Sci J 2015;86:595-602.

3. Weinberg ZG, Szakacs G, Ashbell G, Hen Y. The effect of temperature on the ensiling process of corn and wheat. J Appl Microbiol 2001;90: 561-6.

4. Liu Q, Chen M, Zhang J, Shi S, Cai Y. Characteristics of isolated lactic acid bacteria and their effectiveness to improve stylo (Stylosanthes guianensis Sw.) silage quality at various temperatures. Anim Sci J 2012;83:128-35.

5. Cai Y, Kumai S, Ogawa M, Benno Y, Nakase T. Characterization and identification of Pediococcus species isolated from forage crops and their application for silage preparation. Appl Environ Microbio 1999; 65:2901-6.

6. Kozaki M, Uchimura T, Okada S. Experimental manual of lactic acid bacteria. Tokyo, Japan: Asakurasyoten; 1992. p. 34-37.

7. Chen MM, Liu QH, Xin GR, Zhang JG. Characteristics of lactic acid bacteria isolates and their inoculating effects on the silage fermentation at high temperature. Lett Appl Microbiol 2013;56:71-8.

8. Escalante A, Wacher C, Farrés A. Lactic acid bacterial diversity in the traditional Mexican fermented dough pozol as determined by 16S rDNA sequence analysis. Int J Food Microbiol 2001;64:21-31.

9. Ennahar S, Cai Y, Fujita Y. Phylogenetic diversity of lactic acid bacteria associated with paddy rice silage as determined by $16 \mathrm{~S}$ ribosomal DNA analysis. Appl Environ Microbiol 2003;69:444-51.

10. Shao T, Zhang L, Shimojo M, Masuda Y. Fermentation quality of Italian ryegrass (Lolium multiflorum lam.) silages treated with encapsulatedglucose, glucose, sorbic acid and pre-fermented juices. Asian-Australas J Anim Sci 2007;20:1699-704.

11. Playne MJ, McDonald P. The buffering constituents of herbage and of silage. J Sci Food Agric 1966;17:264-8.

12. Murphy RP. A method for the extraction of plant samples and the determination of total soluble carbohydrates. J Sci Food Agric 1958;9: 714-7.

13. Kleinschmit DH, Schmidt RJ, Kung LK Jr. The effects of various antifungal additives on the fermentation and aerobic stability of corn silage. J Dairy Sci 2005;88:2130-9.

14. Krishnamoorthy U, Muscato TV, Sniffen CJ, Van Soest PJ, Nitrogen fractions in selected feedstuffs. J Dairy Sci 1982;65:217-25.

15. Pang HL, Qing GY, Tan ZF, et al. Natural populations of lactic acid bacteria associated with silage fermentation as determined by phenotype, $16 \mathrm{~S}$ ribosomal RNA and $r e c A$ gene analysis. Syst Appl Microbiol 2011;34:235-41.

16. Bjorkroth KJ, Schillinger U, Geisen R, et al. Taxonomic study of Weissella confusa and description of Weissella cibaria sp. nov., detected in food and clinical samples. Int J Syst Evol Microbiol 2002;52:141-8.

17. Weinberg ZG, Ashbell G, Azrieli A, Brukental I. Ensiling peas, ryegrass and wheat with additives of lactic acid bacteria (LAB) and cell wall degrading enzymes. Grass Forage Sci 1993;48:70-8.

18. Zahiroddini H, Baah J, Absalom W, Mcallister TA. Effect of an inoculant and hydrolytic enzymes on fermentation and nutritive value of whole crop barley silage. Anim Feed Sci Technol 2004;117:317-30.

19. Lin C, Bolsen KK, Brent BE, Fung DYC. Epiphytic lactic acid bacteria succession during the pre-ensiling and ensiling periods of alfalfa and maize. J Appl Microbiol 1992;73:375-87.

20. McDonald P, Henderson AR, Heron SJE. The biochemistry of silage. 2nd ed. Marlow, UK: Chalcombe Publications; 1991.

21. Cai Y, Uegaki R, Fujita Y. Lactic acid bacteria isolated from forage crops and silage fermentation. In: Gomide JA, da Silva SC, Mattos WRS editors. Proceedings of the XIX International Grassland Congressgrassland Ecosystems: An Outlook into the 21st Century. 2001. Sao Paolo: FEALQ; 2001. p. 777-8.

22. Zhang JG, Kawamoto H, Cai Y. Relationships between the addition rates of cellulase or glucose and silage fermentation at the different temperatures. Anim Sci J 2010;81:325-30.

23. Song S, Bae DW, Lim K, Griffiths MW, Oh S. Cold stress improves the ability of Lactobacillus plantarum 167 to survive freezing. Int J Food Microbiol 2014;191:135-43.

24. Derzelle S, Hallet B, Francis KP, et al. Changes in $c s p L, c s p P$, and cspCmRNA abundance as a function of cold shock and growth phase in Lactobacillus plantarum. J Bacteriol 2000;182:5105-13.

25. Nadeau EM, Russell JR, Buxton DR. Intake, digestibility, and composition of orchardgrass and alfalfa silages treated with cellulase, inoculant, and formic acid fed to lambs. J Anim Sci 2000;78:2980-9.

26. Arriola KG, Kim SC, Adesogan AT. Effect of applying inoculants with 
heterolactic or homolactic and heterolactic bacteria on the fermentation and quality of corn silage. J Dairy Sci 2011;94:1511-6.

27. Heinritz SN, Martens SD, Avila P, Hoedtke S. The effect of inoculant and sucrose addition on the silage quality of tropical forage legumes with varying ensilability. Anim Feed Sci Technol 2012;174:201-10.

28. Tabacco E, Piano S, Revello-Chion A, Borreani G. Effect of Lactobacillus buchneri LN4637 and Lactobacillus buchneri LN40177 on the aerobic stability, fermentation products, and microbial populations of corn silage under farm conditions. J Dairy Sci 2011;94:5589-98.

29. Guo XS, Undersander DJ, Combs DK. Effect of Lactobacillus inoculants and forage dry matter on the fermentation and aerobic stability of ensiled mixed-crop tall fescue and meadow fescue. J Dairy Sci 2013;96:1735-44. 